\title{
EFEKTIFITAS PENAMBAHAN MEDIA ORGANIK EKSTRAK UBI JALAR (Ipomoea batatas L) PADA PERTUMBUHAN SUBKULTUR ANGGREK Cattleya sp.
}

\author{
Shinta Nurdika Meilani ${ }^{1)}$, Septarini Dian Anitasari ${ }^{2)}$, Fatimatuz Zuhro ${ }^{3)}$ \\ 1) 2) 3) Pendidikan Biologi FPMIPA IKIP PGRI Jember \\ email: septarinidian@yahoo.co.id
}

Diterima 12 Januari 2017, Disetujui 28 Maret 12017

\begin{abstract}
Orchids (Chattleya sp) is popular plant which is favorted by peoples and has high economic value. It's price Rp. 562,000/plant. Tissue culture technique is needed to produce this flower quickly than conventional technique. This study have aims to determine the effect of some medium concentration of organic sweet potato (Ipomoea batatas $L$ ) on growing Cattleya sp and for knowing the best of concentration on the growth of Chattleya sp. The method used was Completely Random Design with four of factors, that is: $0 \mathrm{~g} / \mathrm{L}, 75 \mathrm{~g} / \mathrm{L}, 150 \mathrm{~g} / \mathrm{L}$, and $300 \mathrm{~g} / \mathrm{L}$. The results were analyzed with Anova test and Duncan test multiple ranger test at the level of $5 \%$. Each treatment was repeated six times. Parameters were observed are the number of new shoots, long leaf, number of leaves, leaf width, long roots, and height of the plant for 5 weeks. Based on the results of analysis showed that the sweet potato extract on $150 \mathrm{~g} / \mathrm{L}$ concentration give the best results in long root parameter, the concentration of $75 \mathrm{~g} / \mathrm{L}$ gived the best results to long leaf parameter and concentration of $300 \mathrm{~g} / \mathrm{L}$ gived the best effect against leaf width. Same concentrations of sweet potato did not give significantly effect to number of new shoots, plantlets height, and number of leaves.
\end{abstract}

Keywords: Extract Of Sweet Potato (Ipomoea Batatas L), Orchids Chattleya sp, Tissue Culture

\section{PENDAHULUAN}

Tanaman anggrek Cattleya sp merupakan famili Orchidaceae yang menjadi salah satu tanaman hias yang populer di seluruh dunia. Tanaman ini memiliki jenis, variasi bentuk, warna, dan karakter bunga yang sangat indah dan unik (Qosim, 2012). Jumlah tanaman anggrek yang ada di dunia yaitu sekitar $25.000-$ 30.000 spesies, salah satudiantaranyaadalah jenis anggrek Cattleya sp. Keindahan dan kecantikan bunganya membuat tanaman ini disebut queen of flower. Di Indonesia anggrek Cattleya sp merupakan tanaman yang mempunyai nilai ekonomis tinggi, baik untuk bunga pot maupun untuk bunga potong (Kasutjianingati dan Irawan, 2013). Anggrek ini banyak dimanfaatkan sebagai hiasan pada acara pernikahan, lebaran, natal, tahun baru, dan ulang tahun. Selain itu digunakan untuk memenuhi kebutuhan karangan bunga, ucapan selamat, rangkaian bunga meja hotel, restoran, perkantoran dan bank (AMARTA, 2007).
Menurut Departemen Pertanian (2015), sekitar $20 \%$ masyarakat indonesia menyukai anggrek potong jenis Cattleya sp.. Permintaan pasar akan anggek Cattleya sp. Semakin meningkat. Berkaitan dengan banyaknya permintaan untuk memenuhi kebutuhan tersebut, anggrek Cattleya sp. memiliki nilai ekonomi cukup tinggi dan potensial untuk dikembangkan secara komersial (Andri dan Tumbuan, 2015).

Upaya pemenuhan permintaan pasar akan anggrek Cattleya sp. selama ini menggunakan teknik konvensional dan teknik kultur jaringan. Kelemahan menggunakan teknik konvensional adalah memerlukan waktu yang cukup lama, tidak praktis, dan tidak menguntungkan secara komersial karena jumlah anakan yang diperoleh sangat terbatas (Ning, 2013). Teknik konvensional biasanya dapat berupa stek batang, pembelahan rumpun, atau pemisahan anakan (split) (Gunawan, 2007). Teknik kultur jaringan memiliki keuntungan yaitu menghasilkan 
tanaman baru dengan jumlah yang banyak dan dalam waktu yang singkat (Ning, 2013). Optimasi teknik kultur jaringan terus dilakukan dalam upaya mempercepat perbanyakan anggrek Cattleya sp. Teknik ini hanya membutuhkan sebagian kecil dari tanaman yang digunakan untuk memperoleh bibit yang banyak, homogen serta memiliki sifat yang sama dengan induknya (BALITHUT, 2013). Teknik kultur jaringan dapat dilakukan dengan memodifikasi media dengan penambahan persenyawaan organik komplek (Untari dan Puspitaningtyias, 2006). Media organik berupa Buah atau sayuran dapat dijadikan media kultur dengan syarat tidak mengandung zat berbahaya ataupun menghambat pertumbuhan tanaman (Silviasari, 2010). Penambahan media organik tersebut dapat mengoptimalkan pertumbuhan anggrek Cattleya sp. (Untari dan Puspitaningtyias, 2006).

Salah satu media organik yang dapat dimanfaatkan adalah jenis ubi jalar putih (Ipomoea batatas L). Ubi jalar merupakan sumber karbohidrat, protein serta mengandung beberapa macam vitamin seperti vitamin $B$, niacin, vitamin A, riboflavin, terutama kandungan tiamin sebanyak $0,1 \mathrm{mg} / 100 \mathrm{~g}$. Tiamin termasuk vitamin B1 yang berfungsi untuk mempercepat pembelahan sel meristem akar (Untari dan Puspitaningtyas, 2006). Penambahan ekstrak ubi jalar (Ipomoea batatas L) sebagai media organik subkultur anggrek Cattleya sp. dalam penelitian ini diharapkan dapat mempercepat pertumbuhan anggrek Cattleya sp. Penelitian ini menggunakan optimasi variasi dengan konsentasi $0 \mathrm{~g} / \mathrm{L}, 75 \mathrm{~g} / \mathrm{L}$, $150 \mathrm{~g} / \mathrm{L}$ dan $130 \mathrm{~g} / \mathrm{L}$ yang bertujuan untuk mengetahui efektifitas penambahan media organik pada pertumbuhan subkultur anggrek Cattleya sp.

\section{METODE}

\section{Sterilisasi Alat dan Bahan}

Alat - alat yang disterilkan adalah botol kultur (sudah direndam bayclin \pm 2 menit). Alat-alat tersebut dicuci hingga bersih menggunakan sunlight lalu dikeringkan. Setelah kering, dibungkus dengan kertas koran (kecuali botol kultur), kemudian dimasukkan ke dalam autoclave dengan tekanan 15-17,5 psi pada suhu $1200 \mathrm{C}$ selama \pm 20 menit. Sedangkan, penstrerilan bahan organik ubi jalar menggunakan sunlight dan air.

\section{Pembuatan Medium}

Pembuatan medium diawali dengan menimbang ubi jalar sesuai dengan perlakuan $75 \mathrm{~g} / \mathrm{L}, 150 \mathrm{~g} / 1$ dan $300 \mathrm{~g} / \mathrm{L}$, ubi jalar dipotong-potong, menambahkan air aquadest dan diblender. Setelah itu jus ubi jalar disaring untuk diambil ekstraknya. Memasukkan 20 gram gula ke dalam larutan medium sambil diaduk dengan magnetic stirer. Setelah gula tercampur, $\mathrm{pH}$ diukur sampai pada angka 5,8. Kemudian ditambahkan 8 gram agar-agar ke dalam larutan medium diaduk dengan kecepatan 400 - $600 \mathrm{rpm}$ dan dipanaskan dengan $550{ }^{\circ} \mathrm{C}$ selama \pm 5 menit menggunakan maghnetic stirer. Pembuatan larutan medium ini digunakan untuk 24 botol kultur, yang masing-masing botol diisi dengan sekitar $30 \mathrm{ml}$ kemudian botol kultur ditutup dengan plastik atau alumunium foil. Botol -botol kultur yang telah diisi dengan medium tersebut dimasukkan ke dalam autoklaf untuk disterilisasi pada tekanan tekanan $15-17,5$ psi pada suhu $120^{\circ} \mathrm{C}$ selama 40 menit. Selanjutnya botol - botol tersebut disimpan pada rak - rak kultur. Selama satu hingga dua hari botolbotol medium kultur tersebut diamati.

\section{Penanaman Eksplan}

Penanaman eksplan dilakukan di dalam Laminar Air Flow Cabinet. Botol kultur terlebih dahulu dipanasi di bagian mulut dan dalam botol untuk mencegah kontaminasi. Selama penanaman mulut botol selalu didekatkan dengan api bunsen. Selanjutnya eksplan diambil menggunakan pinset steril yang setiap digunakan terlebih dahulu dicelupkan kedalam alkohol dan dipanaskan di atas api bunsen. Kemudian eksplan dibersihkanatau distrerilkandengan aquades, setelah itu planlet dimasukkan ke dalam botol kultur dan mulut botol kembali 
dipanasi kemudian botol kultur ditutup dengan kertas alumunium foil dan plastik wrap. Pemeliharaan botol-botol kultur dilakukan dengan cara diletakkan pada rak-rak kultur sesuai dengan perlakuannya yang kondisi ruangannya diatur pada suhu $18-20^{\circ} \mathrm{C}$ menggunakan pendingin ruangan. Botol-botol tersebut setiap dua hari sekali disemprot dengan spirtus atau alkohol untuk mencegah kontaminasi.

\section{HASIL DAN PEMBAHASAN}

Hasil analisis menggunakan uji Anova dan Duncan pada taraf signifikan 5\% dengan SPSS 17.0. menunjukkan bahwa pemberian variasi konsentrasi ubi jalar (Ipomoea batatas L) memberikan pengaruh berbeda nyata pada beberapa parameter antara lain : panjang akar, lebar daun, dan panjang daun, tetapi tidak berbeda nyata pada pertumbuhan jumlah daun, tinggi planlet, dan tunas baru.

Tabel 1. Hasil Pengamatan terhadap Planlet Anggrek Chattleya sp

\begin{tabular}{|c|c|c|c|c|c|c|}
\hline \multirow[b]{2}{*}{ No } & \multirow[b]{2}{*}{ Parameter } & \multirow[b]{2}{*}{ Anova } & \multicolumn{4}{|c|}{ Ujii Duncan 5\% } \\
\hline & & & $\begin{array}{c}0 \mathrm{~g} / \mathrm{L} \\
(\mathrm{A})\end{array}$ & $\begin{array}{c}75 \mathrm{~g} / \mathrm{L} \\
\text { (B) }\end{array}$ & $\begin{array}{c}150 \mathrm{~g} / \mathrm{L} \\
\text { (C) }\end{array}$ & $\begin{array}{c}300 \mathrm{~g} / \mathrm{L} \\
\text { (D) }\end{array}$ \\
\hline 1 & Panjang akar & $.000^{*}$ & $.00000 \mathrm{a}$ & $.05033 \mathrm{ab}$ & $.28750 \mathrm{c}$ & $.10833 b$ \\
\hline 2 & Lebar daun & $.016^{*}$ & $.18167 \mathrm{ab}$ & $.11583 \mathrm{a}$ & $.16417 \mathrm{ab}$ & $.23333 b$ \\
\hline 3 & Panjang daun & $.030^{*}$ & $.14167 \mathrm{a}$ & $.34300 \mathrm{~b}$ & $.17250 \mathrm{a}$ & $.12583 a$ \\
\hline 4 & Jumlah daun & $.574 \mathrm{~ns}$ & - & - & - & - \\
\hline 5 & Jumlah tunas baru & $.618 \mathrm{~ns}$ & - & - & - & - \\
\hline 6 & Tinggi planlet & $.384 \mathrm{~ns}$ & - & - & - & - \\
\hline$\overline{\text { Catata }}$ & $\begin{array}{ll}\text { l: } & \text { *: berbeda signif } \\
& \text { - ns : berbeda tida } \\
& \text { - Notasi a, b, ab, d }\end{array}$ & 1 & $D^{2}$ & s & ikan $5 \%$ & \\
\hline
\end{tabular}

Kehadiran akar sangat dibutuhkan tanaman, karena berfungsi sebagai sebagai penyerap nutrisi dari media, akar juga berperan sebagai tumbuh tegaknya tanaman (Agriani, 2010). Berdasarkan hasil statistik anova dan uji Duncan, pemberian ekstrak ubi jalar dengan beberapa konsentrasi menghasilkan tingkat pertumbuhan yang berbeda. Pada parameter panjang akar pemberian ekstrak ubi jalar dengan konsntrasi $150 \mathrm{~g} / \mathrm{L}$ mempunyai pengaruh yang terbaik dibandingkan dengan konsentrasi yang lainnya.

Hasil penelitian ini sejalan dengan dengan penelitian yang telah dilakukan oleh Untari dan Puspitaningtyas (2006), yang menunjukkan hasil bahwa penambahan ekstrak ubi jalar $150 \mathrm{~g} / \mathrm{L}$ memberikan peningkatan rata-rata panjang akar yang lebih tinggi daripada konsentrasi lainnya. Hal ini dikarenakan pada ubi jalar mengandung $\mathrm{Fe}, \mathrm{Ca}$, niacin, Vitamin $\mathrm{A}$, Riboflavin dan terutama Tiamin termasuk vitamin $\mathrm{B} 1$ sebanyak $0,01 \mathrm{mg} / 100 \mathrm{~g}$ yang mampu merangsang pembelahan sel pada meristem akar, selanjutnya diikuti oleh proses pemanjangan dan pembesaran sel (Widiastoety et.al , 2009), serta berfungsi sebagai koenzim dalam reaksi menghasilkan energi (Agriani, 2010). Pertumbuhan akar yang baik hanya terjadi jika media tumbuhnya dapat mendukung keperluan akar (Garvita dan Elizabeth, 2011).

Pemberian ubi jalar dengan konsentrasi $300 \mathrm{~g} / \mathrm{L}$ memberikan pengaruh terbaik terhadap lebar daun, tetapi hasilnya tidak berbeda nyata dengan konsentrasi 0 g/L dan 150 g/L. Menurut Agriani (2010) lebar daun sangat berpengaruh untuk melakukan fotosintesis, semakin lebar daun maka fotosintesis yang dilakukan akan semakin baik. Salah satu kandungan yang terdapat pada ubi jalar adalah unsur $\mathrm{K}(260 \mathrm{mg} / 100 \mathrm{~g})$ dan $\mathrm{Mg}(26 \mathrm{mg} / 100$ g) (Garvita dan Elizabeth, 2011) yang berperan memperlancar proses fotosintetis, pembentukan klorofil dan enzim proses 
sintesis protein (Taufik, 2014).

Ekstrak ubi jalar juga memberikan sumbangan karbohidrat sebagai sumber energi untuk pertumbuhan daun planlet (Silviasari, 2010), dan juga mengandung gula $2,38 \%$, dan mineral $71,1 \%$ yang dapat menstimulir proliferasi jaringan, memperlancar metabolisme dan respirasi, sehingga memberikan hasil yang baik terhadap pertumbuhan tinggi planlet, jumlah dan luas daun anggrek (Garvita dan Elizabeth, 2011).

Bertambahnya jumlah daun, ukuran panjang serta lebar daun maka semakin besar pengaruhnya terhadap pertumbuhan tanaman (Sylvia, 2009). Kandungan nutrisi yang terkandung dalam senyawa organik ubi jalar, terutama kandungan karbohidrat $(20,1 \%)$ yang merupakan bahan dasar untuk menghasilkan energi dalam proses respirasi dan bahan pembentuk sel-sel baru, juga berperan dalam proses metabolisme dan biosintesis hormon secara endogen seperti auksin, sitokinin dan giberelin akar (Garvita dan Elizabeth, 2011). Salah satu fungsi auksin yang lain adalah mempengaruhi pertambahan panjang dan pertumbuhan batang (Dewi, 2008).

Semakin tinggi konsentrasi ekstrak ubi jalar $(300 \mathrm{~g} / \mathrm{L})$, panjang daun justru semakin menurun. Menurut Agriani (2010), terjadinya penurunan panjang daun pada taraf konsentrasi lebih dari $150 \mathrm{~g} / 1$ disebabkan oleh terganggunya metabolisme yang diakibatkan oleh kadar gula yang lebih tinggi pada ubi, sehingga dapat menghambat pertumbuhan sel-sel somatik.

Penambahan ekstrakubijalarterhadap parameter jumlah daun menunjukkan hasil tidak berbeda nyata berdasarkan uji anova pada tabel 1. Semakin tinggi konsentrasi ekstrak ubi yang diberikan menunjukkan kecenderungan semakin meningkatnya pada rata - rata jumlah daun. Penambahan ekstrak ubi jalar dengan konsentrasi 300 $\mathrm{g} / \mathrm{L}$ memberikan hasil yg terbaik di antara perlakuan yang lainnya.

Hasil Penelitian ini sejalan dengan penelitian yang telah dilakukan oleh Agriani (2010), pada planlet anggrek persilangan phalaenopsis pinlong Cinderella $\times$ Vanda tricolor, yang menunjukkan bahwa pada perlakuan ekstrak ubi jalar dengan konsentrasi $300 \mathrm{~g} / \mathrm{L}$ memberikan hasil optimal terhadap jumlah daun dan didukung oleh kandungan unsur makro dan mikro yang terdapat pada ubi jalar sehingga memeberikan pengaruh pada pertumbuhan planlet anggrek Chattleya sp (Garvita dan Elizabeth, 2011).

Pada parameter jumlah tunas pemberian beberapa konsentrasi ekstrak ubi juga tidak menunjukkan hasil yang berbeda nyata. Pengaruh penambahan konsentrasi ekstrak ubi jalar juga memiliki kecenderungan, dimana semakin tinggi konsentrasi ubi, maka jumlah tunas baru yang terbentuk semakin banyak. Tunas baru paling banyak diperoleh pada konsentrasi ekstrak ubi jalar $300 \mathrm{~g} / \mathrm{L}$.

Bermacam-macam kandungan bahan organik terdapat pada ubi jalar, seperti yang dikatakan Kong et.al (2007) bahwa pemberian bahan organik pada kultur in vitro dapat meningkatkan perkembangan tunas. Pertumbuhan dan perkembangan tunas dipengaruhi juga oleh kandungan auksin dan sitokinin, bila sitokinin lebih tinggi dibandingkan auksin maka akan merangsang tunas (Garvita dan Elizabeth, 2011).

Pada parameter tinggi planlet penambahan konsentrasi ekstrak ubi jalar juga menunjukkan hasil yang berbeda tidak nyata. Tinggi planlet terbesar dihasilkan pada media dengan pemberian ekstrak ubi jalar $75 \mathrm{~g} / \mathrm{L}$. Namun hasil ini tidak berbeda nyata dengan konsentrasi $0 \mathrm{~g} / \mathrm{L}, 150 \mathrm{~g} / \mathrm{L}$, dan $300 \mathrm{~g} / \mathrm{L}$. Respon eksplan tergantung dari tingkat konsentrasi penambahan senyawa organik, spesies dan jenis eksplan yang digunakan (Garvita dan Elizabeth, 2011). Kandungan bahan organik yang terdapat pada ubi jalar diduga memberikan pengaruh yang baik terhadap tinggi plantlet (Kong et.al , 2007).

Hasil yang tidak berbeda nyata pada parameter jumlah daun dan jumlah tunas baru, kemungkinan karena planlet memerlukan waktu yang lebih lama untuk membentuk tunas baru dan jumlah daun. 
Sebagaimana pendapat Rupawan et.al, (2014) yang menyatakan bahwa untuk pengamatan tinggi planlet, jumlah tunas, dan jumlah daun membutuhkan waktu pengamatan minimal 9 MSP (minggu setelah penanaman) atau selama 3 bulan.

\section{SIMPULAN}

Pemberian beberapa konsentrasi ubi jalar memberikan pengaruh berbeda nyata terhadap parameter panjang akar, lebar daun, dan panjang daun. Sedangkan, pada parameter jumlah daun, jumlah tunas baru, dan tinggi planlet menunjukkan hasil yang tidak berbeda nyata. Penambahan ekstrak ubi pada konsentrasi $150 \mathrm{~g} / \mathrm{L}$ memberikan hasil terbaik pada parameter panjang akar, konsentrasi $75 \mathrm{~g} / \mathrm{L}$ memberikan hasil terbaik terhadap parameter panjang daun dan konsentrasi $300 \mathrm{~g} / \mathrm{L}$ memberikan pengaruh terbaik terhadap lebar daun.

\section{DAFTAR PUSTAKA}

AMARTA (Agribusiness Market And Support Activity). (2007). Penilaian Rantai Nilai Sektor Florikultur Tropis di Indonesia. United States Agency for International Development (USAID).

Andri, Kuntoro, B., dan Tumbuan, Alfa, W. J. F. (2015). Potensi Pengembangan Agribisnis Bunga Anggrek di Kota Batu Jawa Timur. Jurnal LPPM Bidang EkoSosBudkum. 2 (1).

Anonim. 2016. Harga bunga anggrek. (Online) tersedia : http://www. priceza.co.id (25 juli 2016).

Anonim. (2016). Budidaya Pertanian Ubi Jalar/Ketela Rambat Ipomoea batatas L. Bantul. (Online) tersedia : http:// warintek.bantulkab.go.id (5 April 2016).

Agriani, S.M. (2010). Pengaruh Konsentrasi Ekstrak Ubi Jalar Dan Emulsi Ikan Terhadap Pertumbuhan Plb Anggrek Persilangan Phalaenopsis Pinlong Cinderella X Vanda Tricolor Pada Media Knudson C. Fakultas Pertanian. Universitas
Sebelas Maret Surakarta.

Astuti, Winda Dwi. (2014). Bioteknologi (Subkultur). Fakultas Pertanian. Universitas Jember.

Balai Besar Litbang Bioteknologi Dan Sumber Daya Genetik Pertanian. (2015). Dasar - Dasar Teknik Kultur Jaringan Tanaman. Artikel. Balitbangtan. Bogor. (Online) tersedia: http://biogen.litbang. pertani an.go.id/index. php/2014/07/ ringkasan -kuliah-prof-r-dr-ikamariska-s-1-dasar-dasar-teknik (15 Desember 2015).

Balai Besar Pelatihan Pertanian (BBPP). (2014). Diklat Teknis Kultur Jaringan 2013. Artikel. Kementrian Pertanian. Lembang.(15 Desember 2015).

BALITHUT (Balai Litbang Lingkungan Hidup Dan Kehutanan). (2013). Perbanyakan Tanaman Melalui Kultur Jaringan. Makassar. (Online) tersedia: http://balithutmakassar.org. (09 Mei 2016).

Departemen Pertanian. (2015). Prospek dan Arah Pengembangan Agribisnis Anggrek. Badan Litbang Pertanian. (Online) tersedia: http://www. litbang.pertanian.go.id/special/ komoditas/ (18 Maret 2016).

Dewi, I.R. (2008). Peranan dan Fungsi Fitohormon bagi Pertumbuhan Tanaman. Skripsi. Fakultas Pertanian. Universitas Padjajaran. Bandung

Garvita, R., V dan Elizabeth, H. (2011). Pengaruh Penambahan Berbagai Kadar Pisang dan Ubi Jalar Pada Pertumbuhan Kultur Tiga Jenis Phalaenopsis. Buletin Kebun Raya. 14 (2).

Gunawan, L. W. (2007). Budidaya Anggrek. Edisi Revisi. Penebar Swadaya. Jakarta.

Hanifa, Hanna. (2013). Inisiasi Kultur Dan Subkultur. (Online) tersedia : http://hannahanipeh.blogspot. co.id/2013/10/laporan-praktikumkultur-jaringan.html (07 Maret 
2016).

Hendaryono, Daisy., P., S dan Wijayani, Ari. (2012). Teknik Kultur Jaringan (Pengenalan dan Petunjuk Perbanyakan Tanaman Secara Vegetatif - Modern). Yogyakarta. Kasinius.

Henuhili, Victoria. (2013). Kultur Jaringan Tanaman. FMIPA. UNY. Yogyakarta.

ITIS.gov. (2016). Integrated taxonomic information system. (Online) tersedia : $\quad$ http://www.itis.gov/servlet/ SingleRpt (12 Maret 2016).

ITIS.gov. (2016). Integrated taxonomic information system. (Online) tersedia :(12 Maret 2016).

Julian. (2011). Inokulasi dan subkultur anggrek. (Online) tersedia : http:// julianzun3. (12 Mei 2016).

Kasutjianingati, dan R. Irawan. (2013). Media Alternative Perbanyakan In Vitro Anggrek Bulan (Phalaenopsis amabilis). Jurnal Agroteknos. 3 (3) : 184 - 189.

Kementrian Pertanian Republik Indonesia. Direktorat budidaya tanaman hias dan direktorat jendral holtiultura. (2010). Informasi Teknis Tanaman Hias Pot. (Online) tersedia : http:// florikultura.hortikultura.pertanian. go.id/ (12 Maret 2016)

Kurniasih, S dan Munarti. (2015). Perbandingan Kandungan Mineral dan Vitamin B1 Beberapa Jenis Ubi Jalar (Ipomoea Batatas L.). JURNAL : Prosiding Semirata 2015 bidang MIPA BKS-PTN Barat. Universitas Tanjungpura Pontianak. (200 - 206).

Kong, Q., Yuan, S. Y, Vegvari, Gy. 2007. Micropopagation of an Orchid Dendrobium strongylathum Rchb.f. International Journal of Horticultural Science. 13 (1): 61-64.

Maiden, Rylai T., C. 2016. Forum tanya jawab biologi "Apa pengertan Subkultur pada kultur jaringan?". (Online) tersedia : http://www. bhataramedia.com/forum/a (12 Mei 2016).

Ning. (2013). Kultur In Vitro Dan Konvensional Anggrek. (Online) tersedia : http://neechatree16.com/ index.php/2015/10/17/kult(09 Mei 2016).

Nurlaiala. (2011). Subkultur Anggrek Pada Media MSO. FP MIPA. Universitas Negeri Jakarta.

Prasetyo, Cahyo., H. (2009). Teknik Kultur Jaringan Anggrek Dendrobium Sp. Di Pembudiyaan Anggrek Widorokandang Yogyakarta. Fakultas Pertanian. Universitas Sebelas Maret Surakarta.

Purwanto, A., W dan Semiarti, E. (2009). Pesona Kecantikan Anggrek Vanda. Yogyakarta. Kasinius.

Purwono, dan Purnamawati., H. (2014). Mengenal Ubi Jalar. Dinas Pertanian Tanaman Pangan Dan Holtikultura. Provinsi Kalimantan Selatan. (Online) tersedia : http://distantph.kalselprov. go.id/2014/02/24/mengen (18 Maret 2016).

Putra, V. Hasmana. (2009). Budidaya Dan Prospek Pemasaran Anggrek Bulan Lokal (Phalaenopsis Amabilis) Di Kebun Anggrek Widorokandang Yogyakarta. Fakultas Pertanian Universitas Sebelas Maret. Surakarta.

Qosim, et al. (2012). Pengaruh mutagen etil metan sulfonat terhadap kapasitas regenerasi tunas hibrida phalaenopsis in vitro. J. Hort. 22 (4) : 360 - 365.

Rupawan,I,M., Z., Basri dan Mirni B. (2014). Pertumbuhan anggrek vanda sp pada berbagai berbagai komposisi media secara in vitro. Jurnal : Agrotekbis 2 (5) : $488-494$

Santoso, W., E., Arif dan Estiasih, T. (2014). Jurnal review : Kopigmentasi Ubi Jalar Ungu (Ipomoea batatas var. Ayamurasaki) dengan Kopigmen NA-Kaseinat dan Protein Whey serta 
Stabilitasnya Terhadap Pemanasan. Taufik, Dikdik. (2014). Unsur Hara Makro Jurnal Pangan dan Agroindustri. 2 dan Mikro yang dibutuhkan oleh (4) : $121-127$.

Silviasari, A., D. (2010). Pengaruh konsentrasi ekstrak ubi jalar dan emulsi ikan terhadap pertumbuhan planlet anggrek Dendrobium alice noda $x$ Dendrobium tomie dan Phalaenopsis pinlong Cinderella $x$ Vanda tricolor pada medium vacin dan went. Fakultas pertanian. Universitas Sebelas Maret Surakarta.

Sugiayanto, A. 2015. 7 jenis bunga anggrek ini bisa kamu temukan di indonesia. (Online) http://santaisaja.net/jenisbunga-anggrek. (12 Maret 2016).

Supadmi, Sri. 2009. Studi Variasi Ubi Jalar (Ipomoea batatas .L) Berdasarkan Morfologi, Kandungan Gula Reduksi dan Pola Pita Isozim. Program Pasca Sarjana. Universitas Sebelas Maret. Surakarta. Tanaman. (Online) tersedia : https:// organichcs.com/2014/05/03/unsurmakro-d (07 Agustus 2016).

Sylvia, I. (2009). Pengaruh IBA dan NAA terhadap stek Aglonema Var. Donna Carmen dengan perendaman. Skripsi. Fakultas Pertanian. IPB. Bogor.

Untari, R dan D. Puspitaningtyas. (2006). Pengaruh Bahan Organik dan NAA terhadap Pertumbuhan Anggrek Hitam (Coelogyne pandurata Lindl.) d a 1 a $\mathrm{m}$ Kultur in Vitro. J. Biodiversitas. 7 (3) : 344 - 348

Widiastoety, D., N. Solvia dan S. Kartikaningrum. 2009. Pengaruh thiamin terhadap pertumbuhan plantlet anggrek Oncidium secara in vitro. Jurnal Hortikultura Indonesia 19(1): 35-39. 